\title{
OPTIMASI BUKAAN DENGAN MEMANFAATKAN EFEK WIND TUNNEL PADA RUMAH DERET (STUDI KASUS KAMPUNG DERET PETOGOGAN, JAKARTA)
}

\author{
Anggi Oktovianto', Alwin Suryono ${ }^{2}$ \\ Universitas Katolik Parahyangan \\ 1anggiokto@gmail.com, 2alwin@unpar.ac.id
}

\begin{abstract}
Abstrak: Fenomena konsumsi energi pada rumah tinggal di Indonesia mendorong perancang untuk menerapkan konsep desain pasif sebagai upaya penghematan energi untuk mencapai kenyamanan penghuni tanpa bantuan mekanik atau elektrik. Penelitian ini mengangkat isu yang terjadi di kompleks Kampung Deret Petogogan yaitu rancangan bangunannya yang tidak dapat memanfaatkan efek wind tunnel yang terjadi akibat konfigurasi deret untuk mengoptimalkan pengahawaan alami ke dalam setiap unit hunian. Rancangan yang dimaksud adalah rancangan bukaan yang meliputi letak, tipe, besaran dan elemen yang membantu optimasi bukaan dalam mengalirkan pergerakan udara ke dalam ruang. Tujuan dari penelitian ini adalah untuk mengidentifikasi penyebab tidak mengalirnya udara ke dalam ruang dan mengetahui kriteria rancangan bukaan yang ideal dalam mengoptimalkan penghawaan alami. Pembahasan diawali dengan mendeskripsikan teori rancangan yang terkait hingga menjadi kriteria rancangan ideal. Selanjutnya menganalisis rancangan bukaan eksisting yang dikomparasikan dengan kriteria hingga memunculkan rancangan yang ideal dalam mengoptimalkan penghawaan alami pada setiap ruang dalam bangunan. Hasil dari penelitian ini adalah bentukan rancangan bukaan yang ideal, meliputi penambahan dinding pengarah pergerakan udara untuk mengalirkan pergerakan udara menuju bukaan, pengaturan letak bukaan dan penambahan bukaan atap, pemilihan tipe bukaan yang sesuai pola alliran udara serta mengatur kembali besaran bukaan sesuai dengan kebutuhan penghawaan alami setiap ruang dalam bangunan.
\end{abstract}

Kata kunci: rumah deret, ventilasi, desain pasif

\begin{abstract}
Energy consumption on domestic uses in Indonesia provokes designers to implement passive design concept as an effort to reduce the use of mechanical and electrical solution for household comfort. This research observed Kampung Deret Petogogan which a wind tunnel effect could not accurately provide natural comfort inside the row houses. Openings design was a key element to determine optimization of air movement indoors, including its positions, types, and dimensions. The goals were to identify the causes and determine ideal openings design to optimize air circulation indoors. First assessment involved relevant design theories that conducted as guidelines. Then the existed design openings were examined and compared with guidelines, thus the ideal design openings were generated. The final results concluded multiple solutions for optimizing air movement control. An addition of wing wall, to help control the air movement. Repositioning the openings, both on walls and roofs. The selection of opening types which would be suitable based on air movement pattern. Lastly, redesign the dimension of the openings to fit the needs of natural comfort inside the houses.
\end{abstract}

Keywords: rowhouse, ventilation, passive design

\section{PENDAHULUAN}

Arsitektur perumahan di Indonesia dihadapkan dengan permasalahan konsumsi energi yang mencapai 19\% dari total konsumsi energi (Outlook Energi Indonesia 2016) dan kesenjangan antara kebutuhan dan ketersediaan yang mencapai $\pm 17,2$ juta unit pada tahun 2014 dan meningkat \pm 930 -unit pertahunnya (RPJMN 2014-2019). Hal tersebut mendorong perancang perumahan untuk menerapkan konsep desain pasif sebagai upaya penghematan energi pada bangunan untuk mencapai kenyamanan penghuni tanpa bantuan mekanik atau elektrik (Lechner 1975). 
Pada iklim tropis, penerapan konsep desain pasif difokuskan pada penghawaan alami dikarenakan kondisi lingkungan yang panas dan lembap. Kondisi lingkungan tersebut menyebabkan terbentuknya saturated air envelope yang menghalangi pembuangan panas dan membuat penghuni berkeringat. Cara menghilangkannya adalah hanya dengan mengoptimalkan penghawaan alami ke dalam bangunan dengan memanfaatkan potensi lingkungan yang ada (Koenigsberger 1975). Oleh karena itu, penelitian mengenai penghawaan alami pada perumahan penting untuk dilaksanakan.

Pemerintah Indonesia telah membangun rumah deret bagi masyarakat berpenghasilan rendah untuk meningkatkan kualitas hidup, mengefisienkan lahan dan meminimalisir penggunaan dana tanpa menggusur penghuni dari tempat tinggal sebelumnya. Namun, pada rumah deret tersebut ditemukan adanya indikasi ketidak berhasilan konsep desain pasif dalam mengoptimalkan penghawaan alami yang dilihat dari penggunaan Air Conditioner pada beberapa unit hunian.

Menurut (Boutet 1987), konfigurasi massa deret menyebabkan terjadinya efek wind tunnel yang dapat dimanfaatkan ataupun merugikan jika tidak dirancang dengan tepat. Efek wind tunnel dapat meningkatkan kecepatan pergerakan udara dan menjangkau setiap ruang pada unit hunian. Sebaliknya, rancangan bangunan dengan konfigurasi deret yang tidak tepat dapat menyebabkan aliran udara yang tidak optimal karena kecepatan pergerakan udara yang terus menurun seiring dengan bertambahnya panjang gang, yang dijelaskan pada gambar 1 (Boutet 1987)

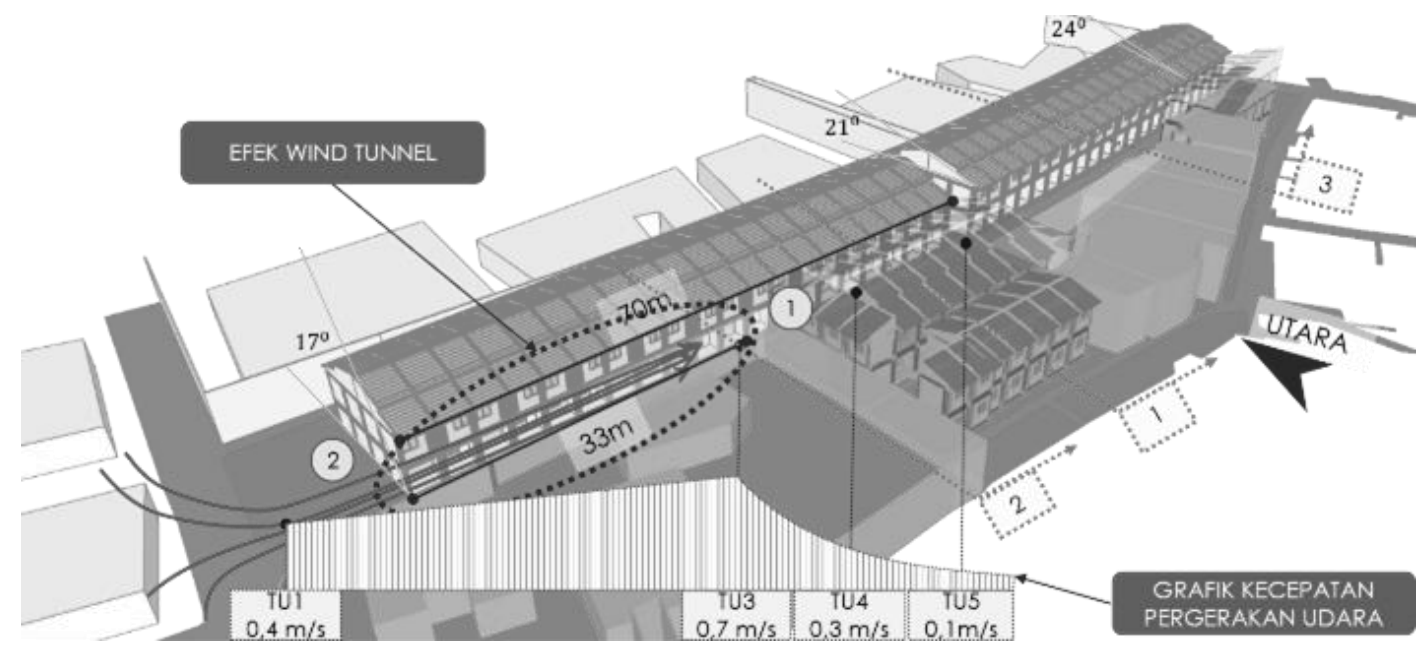

Gambar 1. Efek wind tunnel pada Kampung Deret Petogogan

Penggunaan air conditioner pada unit Kampung Deret Petogogan yang merupakan indikasi permasalahan rancangan yang muncul karena pergerakan udara tidak mengalir ke dalam bangunan dan menimbulkan ketidaknyamanan penghuni terhadap kondisi ruang dalam bangunan. Hal ini perlu diteliti lebih lanjut mulai dari lingkup lingkungan (tata massa bangunan) dan lingkup bangunan (bukaan bangunan).

Berdasarkan permasalahan desain yang telah dikemukakan sebelumnya, Penelitian ini dibatasi dan dirumuskan menjadi pertanyaan yang akan dijawab dalam penelitian, yaitu:

- Apa penyebab tidak optimalnya pemanfaatan efek wind tunnel sehingga tidak dapat mengalirkan pergerakan udara ke dalam ruang? 
- Bagaimana penerapan konsep desain pasif yang ideal pada perancangan tata massa bangunan dalam mengoptimalkan penghawaan alami pada rumah deret?

- Bagaimana penerapan konsep desain pasif yang ideal pada perancangan bukaan bangunan dalam mengoptimalkan penghawaan alami pada rumah deret?

Pembahasan tata massa bangunan akan dibagi menjadi orientasi dan skala (besaran dan spasi antar objek tiga dimensi). Sementara pembahasan bukaan bangunan menjadi letak, tipe dan besaran bukaan serta teknologi untuk membantu optimasi bukaan. Analisis menghasilkan beberapa temuan yang menjadi dasar perumusan solusi desain terhadap permasalahan tersebut.

\section{METODE}

\subsection{Metode Pengambilan dan Pengolahan Data}

Data objek studi diperoleh dari beberapa sumber, yaitu Pusat Litbang Perumahan dan Permukiman Badan Penelitian dan Pengembangan Kementrian Pekerjaan Umum dan Perumahan Rakyat serta observasi secara langsung pada objek studi. Data yang diperoleh berupa data umum Kampung Deret Petogogan Jakarta yang melingkupi data projek, konsep rancangan dan gambar kerja eksisting. Sementara data hasil observasi berpa data pengukuran ulang gambar kerja, pengukuran kondisi termal dan pemetaan arah pergerakan udara.

Observasi dilakukan pada lingkup lingkungan dan bangunan kompleks Kampung Deret Petogogan, Jakarta Selatan. Pada lingkup lingkungan, area yang diteliti dibatasi pada area sirkulasi antar unit yang saling berhadapan dan bertolak belakang dengan unit lainnya (Gambar 2).

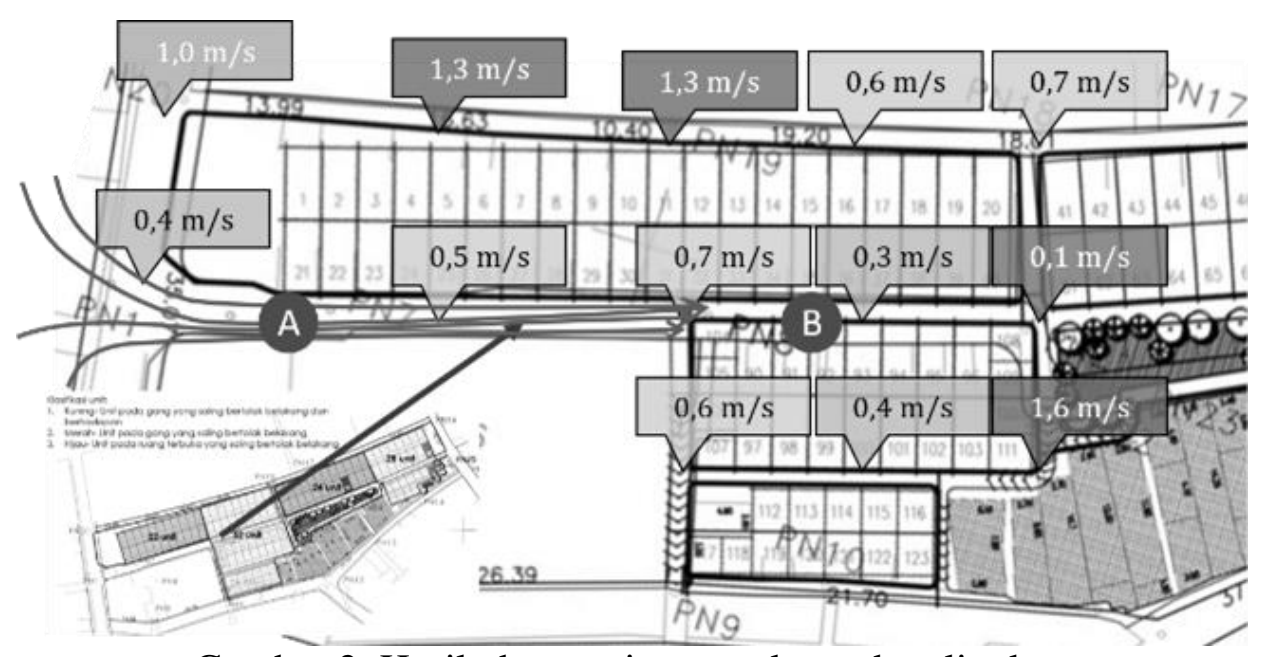

Gambar 2. Hasil observasi pergerakan udara lingkungan

Observasi tersebut menggunakan WBGT (wet bulb globe temperature) meter dan Hot Wire Anemometer (Gambar 3) untuk mendapatkan data pengukuran. Sementara pemetaan arah pergerakan udara menggunakan gambar rencana tapak dan alat tulis. Hasil pengukuran pada tapak (Gambar 2) menunjukan terjadinya peningkatan kecepatan pergerakan udara pada titik (A) yang merupakan penyempitan area sirkulasi. Kecepatan pergerakan udara mencapai maksimum pada area persimpangan dan selanjutnya mengalami penurunan pada titik (B) hingga mencapai titik terendah pada persimpangan berikutnya. 

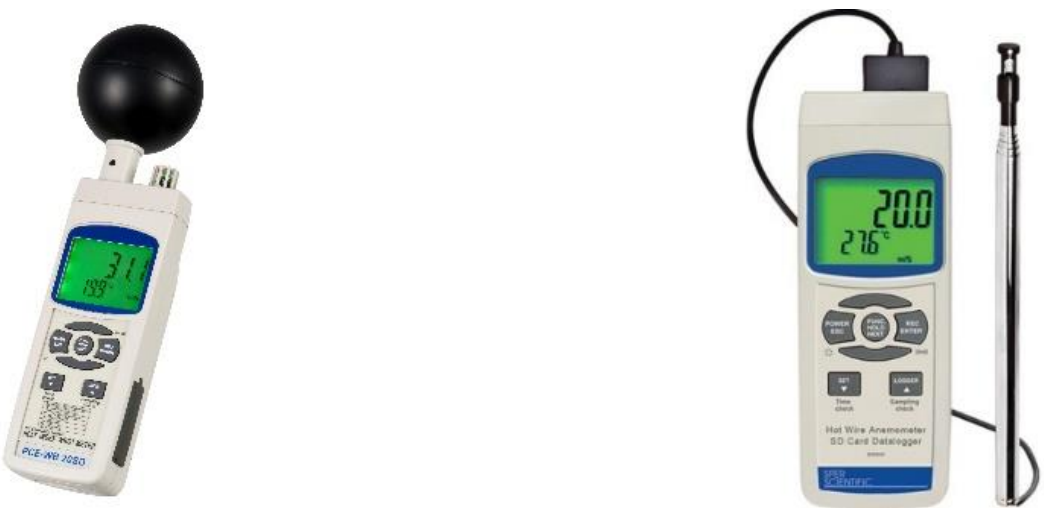

Gambar 3. WBGT (wet bulb globe temperature) meter dan Hot Wire Anemometer

Sementara itu, hasil pengukuran dan pemetaan pergerakan udara pada unit hunian menunjukan tidak adanya aliran pergerakan udara ke dalam ruangan karena pada alat ukur mencatat kecepatan pergerakan udara hanya dapat mencapai angka rata-rata $0,1 \mathrm{~m} / \mathrm{s}$. Hasil pengukuran kondisi termal juga menunjukan angka yang dikategorikan tidak nyaman menurut grafik ETCET dari Houghton dan Yaglou (Gambar 4).

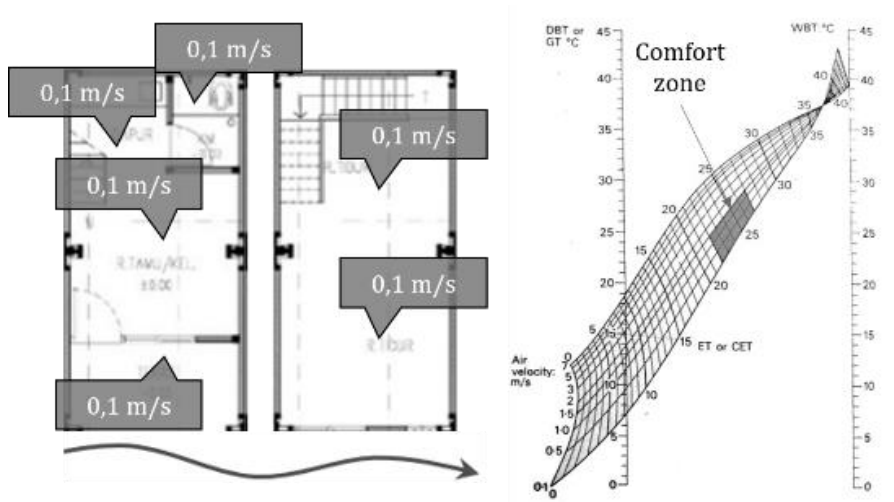

Gambar 4. Hasil observasi pergerakan udara bangunan

\subsection{Metode Pengambilan dan Pengolahan Data}

Data pengukuran dan pemetaan yang telah diperoleh dijadikan acuan dalam menganalisis rancangan tata massa dan bukaan pada bangunan. Data tersebut diolah melalui tabulasi menggunakan software Microsoft Excel 2016, kemudian diterapkan pada grafik ET-CET dan dilakukan perhitungan kebutuhan air change per hour.

Hasil pengolahan data dianalisis lebih lanjut mengenai rancangan tata massa dan bukaan bangunan yang dibantu dengan software Autodesk FlowDesign hingga diketahui penyebab tidak mengalirnya pergerakan udara ke dalam ruang. Temuan tersebut menjadi dasar pedoman perancangan sebagai solusi dalam menerapkan konsep desain pasif yang ideal untuk mengoptimalkan penghawaan alami.

\section{HASIL/TEMUAN}

Analisis dilakukan mulai dari lingkup lingkungan yang melingkupi tata massa dan skala (besaran dan spasi antar objek tiga dimensi) hingga lingkup bangunan dan ruang (letak, tipe, 
besaran dan elemen yang membantu optimasi bukaan). Analisis dan hasil penelitian ini diperoleh berdasarkan data lapangan yang diobservasi, disimulasi dan dikomparasi dengan teori berkaitan.

\subsection{Analisis faktor lingkungan}

Hasil observasi lingkungan Kampung Deret Petogogan menyatakan bahwa terdapat dua arah pergerakan udara dominan yang melalui unit hunian deret, yaitu arah pergerakan udara yang cenderung bergerak searah deretan unit dan ke bagian atas bangunan. (Gambar 5)

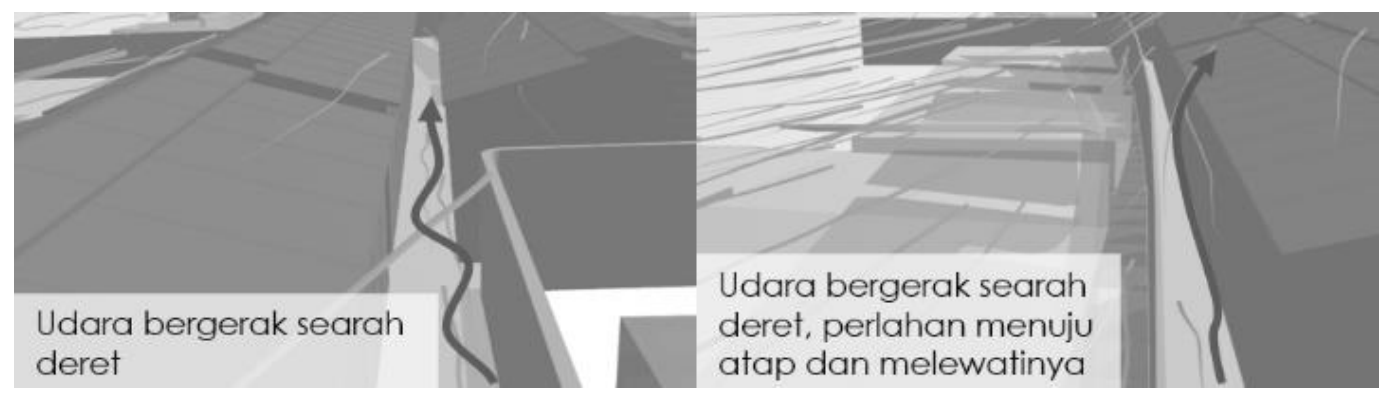

Gambar 5. Hasil observasi pergerakan udara bangunan

Kedua pola aliran udara tersebut merupakan akibat dari karakteristik konfigurasi deret dan direkomendasikan untuk menambahkan dinding pengarah pergerakan udara (Gambar 6) untuk mengarahkan pergerakan udara menuju ke dalam bangunan. (Evans 1980), (Boutet 1987) dan (Brown 2001)
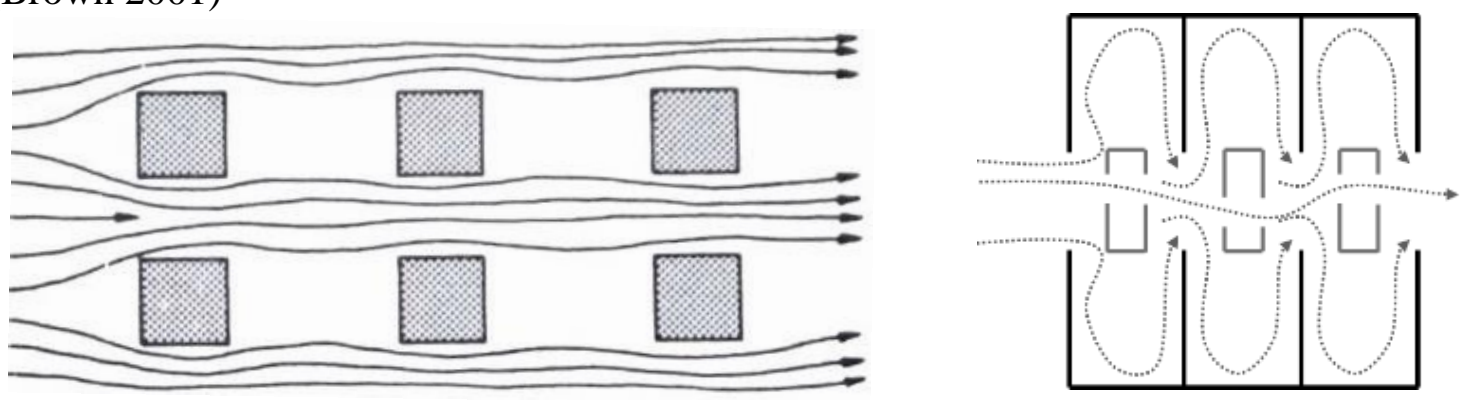

Gambar 6. Karekteristik pola pergerakan udara pada rumah deret dan rekomendasi perancangan

Penggunaan dinding pengarah pergerakan udara yang direkomendasikan sesuai dengan arah pergerakan udara dominan adalah menggunakan dinding pengarah pergerakan udara vertikal pada lantai dasar unit hunian dan dinding pengarah pergerakan udara kombinasi pada lantai atas hunit hunian. (Gambar 7)
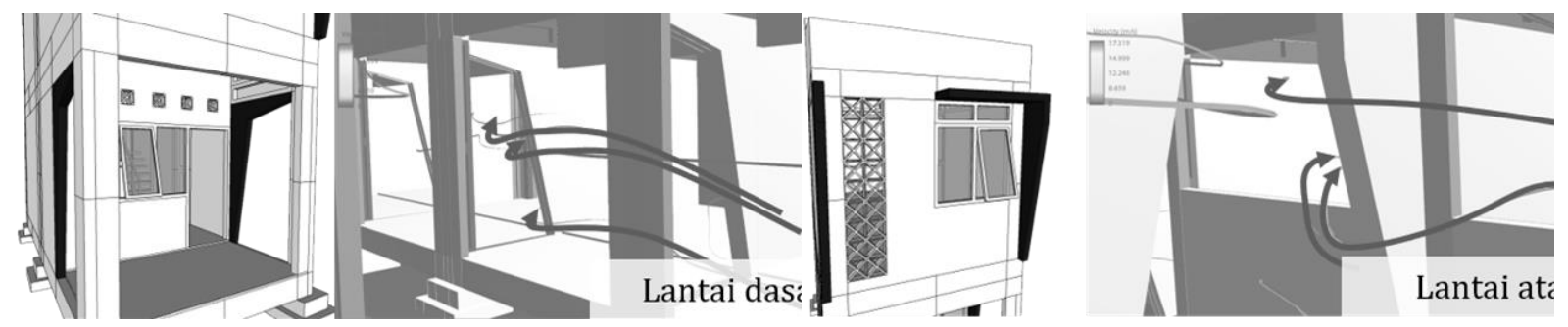

Gambar 7. Sirip pengarah pergerakan udara sesuai pola pergerakan udara lingkungan 
Pada lingkungan juga tercatat efek wind tunnel yang terjadi secara efektif meningkatkan kecepatan pergerakan udara mulai dari unit (1) hingga deret unit hunian mencapai $33 \mathrm{~m}$. Kecepatan pergerakan udara berangsur-angsur menurun mulai dari panjang deret $33 \mathrm{~m}$ hingga titik (2) yang berjarak $60 \mathrm{~m}$ dari titik (1). Kecepatan pergerakan udara mencapai titik terendah, yaitu $0,1 \mathrm{~m} / \mathrm{s}$. (Gambar 8 )

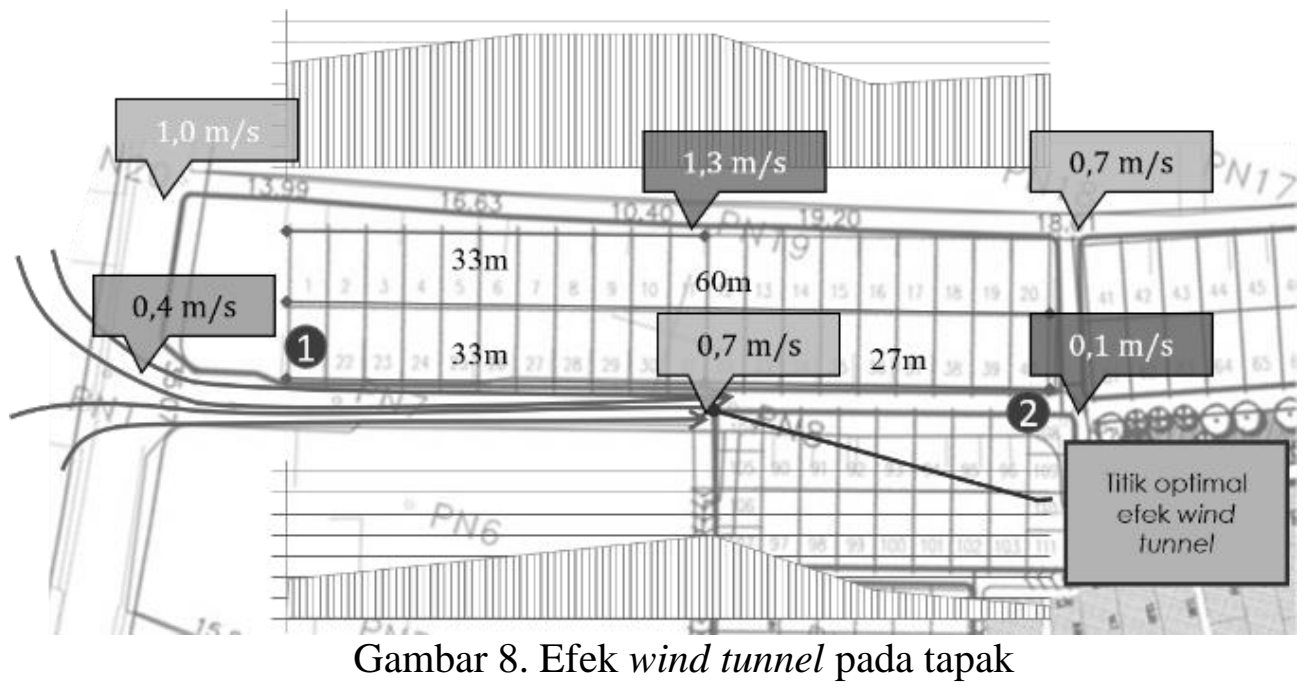

Permasalahan tersebut dapat ditanggulangi dengan mengatur kembali panjang deret unit hunian untuk memanfaatkan efek wind tunnel dengan optimal. Panjang deret unit hunian yang direkomendasikan adalah dibawah angka $33 \mathrm{~m}$. Setelah diuji melalui simulasi, pergerakan udara dapat terdistribusi ke seluruh unit hunian dengan kecepatan yang memadai karena tidak mengalami penurunan kecepatan pergerakan udara akibat deretan unit hunian yang terlalu panjang (Gambar 9).

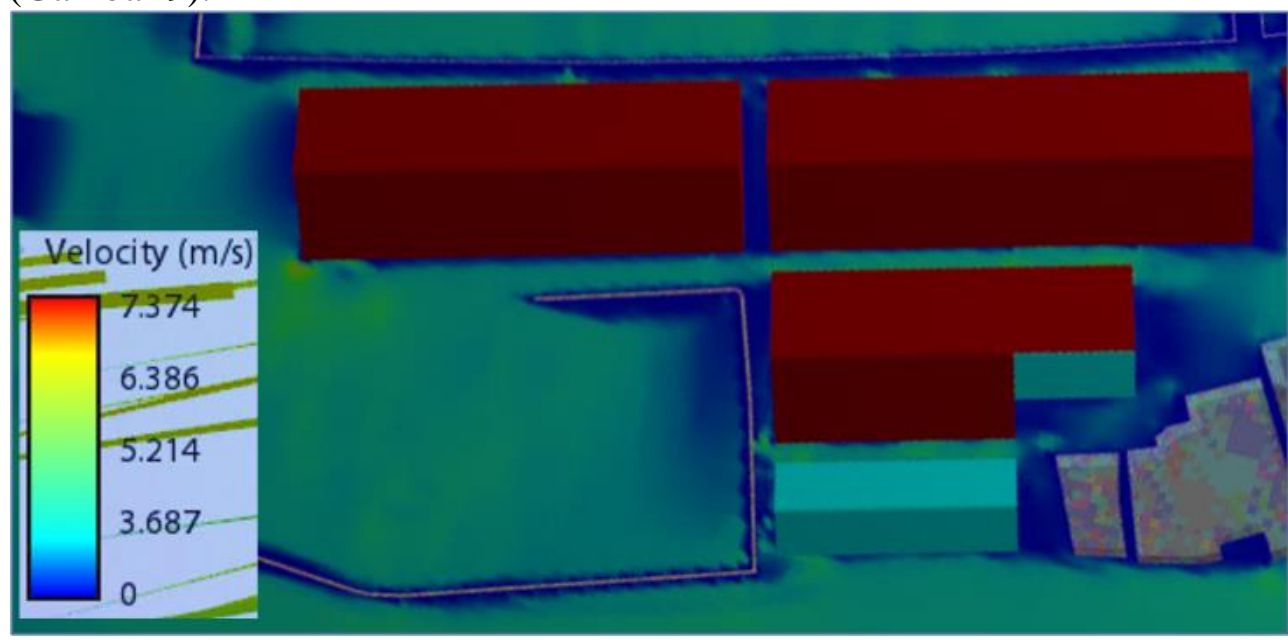

Gambar 9. Simulasi hasil perancangan ulang

\subsection{Analisis bukaan pada bangunan}

Bukaan bangunan dianalisis berdasarkan pengukuran dan pemetaan eksisting serta hasil analisis faktor lingkungan. Berdasarkan hal tersebut, Bukaan bangunan perlu ditunjang oleh dinding pengarah pergerakan udara untuk mengoptimalkan penghawaan alami ke dalam ruang. Bukaan dibagi 4 pembahasan, yaitu letak, tipe, besaran dan dinding pengarah pergerakan udara 
Bukaan pada unit hunian Kampung Deret Petogogan terletak hanya pada satu sisi permukaan dinding. Menurut (Brown 2001), letak tersebut memiliki persentase pengaliran udara yang minim. Letak bukaan yang direkomendasikan adalah letak bukaan yang secara horizontal dapat mengoptimalkan persentase aliran udara dan secara vertikal dapat mengarahkan aliran udara menuju living zone atau 0-2m dari permukaan lantai (Gambar 10).

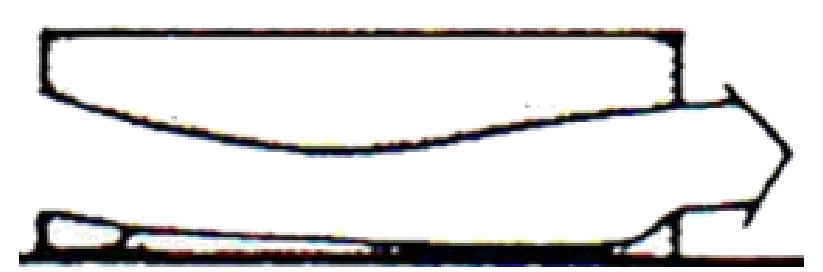

vertikal

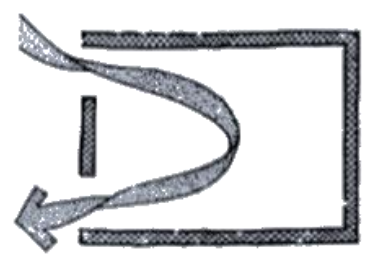

horizontal

Gambar 10. Letak bukaan yang direkomendasikan

Selain itu, tidak adanya bukaan pada atap unit hunian menyebabkan tidak optimalnya penghawaan alami pada ruang dalam. Bukaan atap direkomendasikan untuk digunakan karena dapat menurunkan suhu ruang atap melalui ventilasi silang. Bukaan atap yang paling optimal adalah kombinasi continuous ridge and soffit louvers. Bukaan atap tersebut dapat menurunkan suhu ruang atap mencapai $18,9^{\circ} \mathrm{C}$ pada kecepatan pergerakan udara $0,4-2,4 \mathrm{~m} / \mathrm{s}$ (Gambar 11) (Boutet 1987)
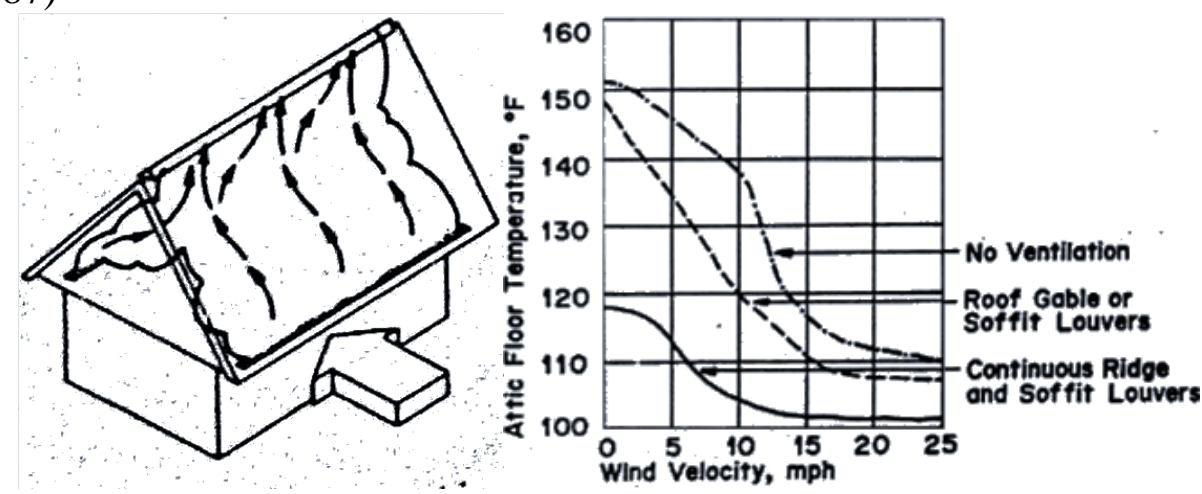

Gambar 11. Bukaan atap continuous ridge and soffit louvers

Bukaan atap tersebut dapat diterapkan pada unit hunian dengan meletakan inlet pada sisi kemiringan atap bagian bawah dan outlet pada sisi kemiringan atap bagian atas. Pergerakan udara yang terjadi pada ruang dalam bangunan akan mengalir dari bagian bawah menuju ruang atap bangunan. (Gambar 12)

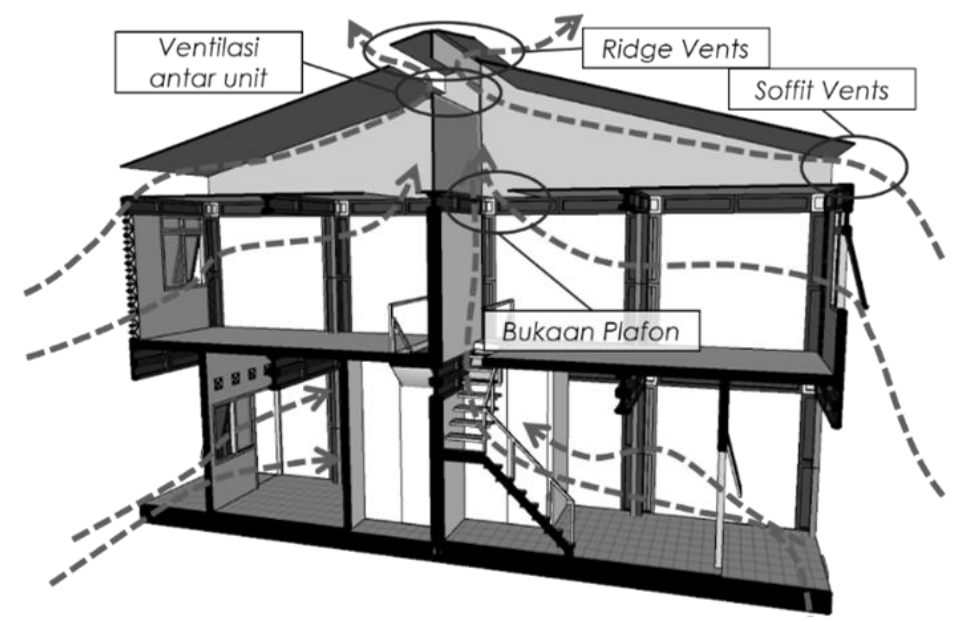

Gambar 12. Aplikasi bukaan atap pada unit hunian 
Tipe bukaan berperan dalam menentukan arah dan kecepatan pergerakan udara yang masuk ke dalam ruang. Tipe bukaan dibagi ke dalam tiga jenis (berlaku untuk bukaan pintu maupun jendela), yaitu bukaan horizontal, vertikal dan screen (Boutet 1987).

Bukaan horizontal menentukan arah pergerakan udara secara vertikal, Bukaan vertikal menentukan arah pergerakan udara secara horizontal dan screen tidak mengubah arah pergerakan udara (Gambar 13). Pemilihan tipe bukaan yang direkomendasikan adalah yang sesuai dengan pola pergerakan udara di luar bangunan dan arah yang diinginkan.

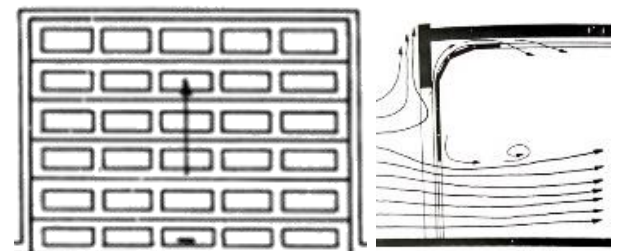

Tipe bukaan horizontal

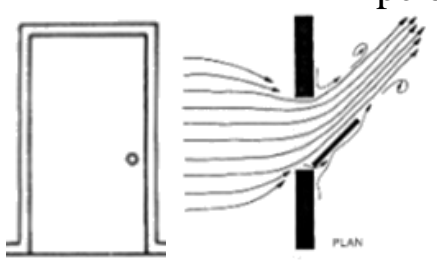

Tipe bukaan vertikal

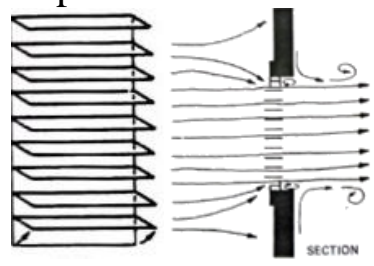

Tipe bukaan screen
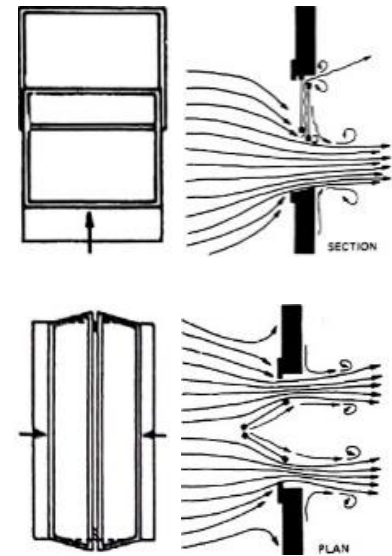

Gambar 13. Aplikasi bukaan atap pada unit hunian

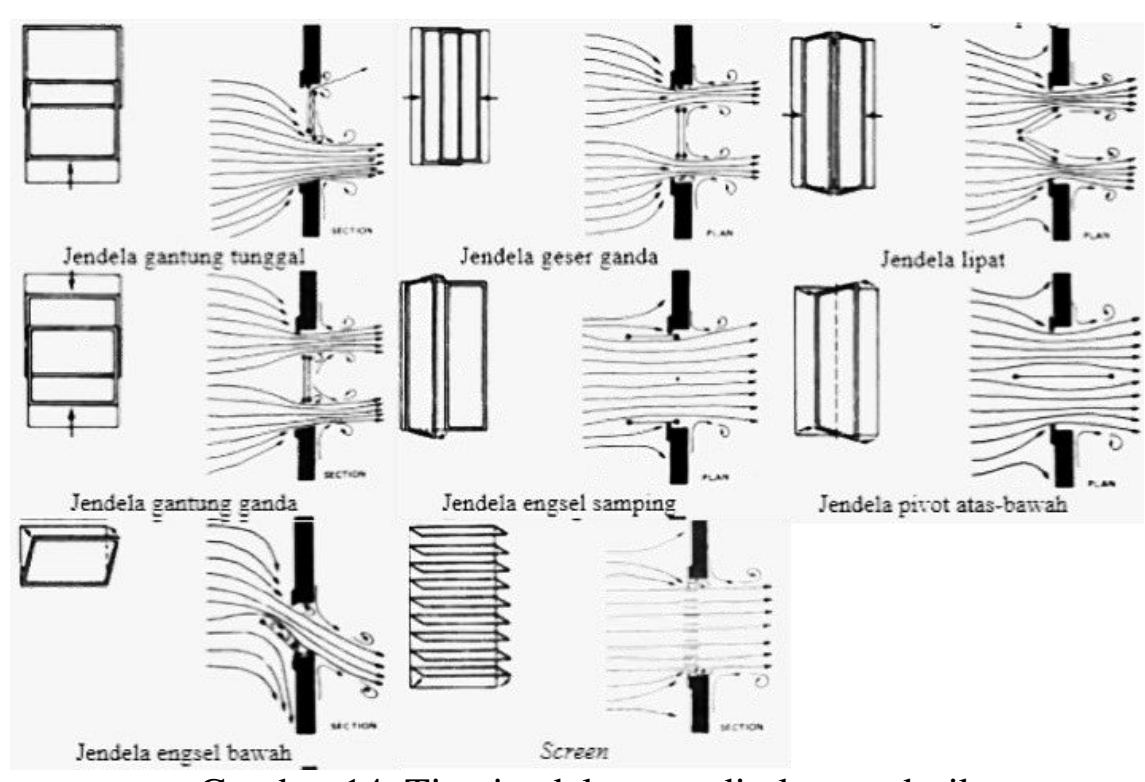

Gambar 14. Tipe jendela yang direkomendasikan 
Tipe bukaan yang digunakan pada unit hunian Kampung Deret Petogogan adalah pintu satu daun, rolling door, jendela engsel atas dan screen. Penggunaan jendela engsel atas pada unit hunian tidak tepat dikarenakan dapat mengarahkan pergerakan udara menuju plafon atau menjauhi area living zone (0-2m). Tipe bukaan yang sesuai dengan pola aliran udara lingkungan yang cenderung bergerak searah deretan unit dan ke bagian atas bangunan adalah tipe bukaan vertikal yang tidak mengubah arah pergerakan udara yang masuk ke dalam bangunan untuk menjauhi area living zone (0-2m). (Gambar 14)

Besaran bukaan berperan terhadap kecepatan pergerakan udara yang masuk ataupun ke luar ruangan. Proses pertukaran udara luar dan dalam dihitung dalam kurun waktu satu jam yang disebut Air Change per Hour (ACH).Perhitungan besaran nilai ACH dapat dihitung dengan rumusan (1) (Latifah 2012).

Faktor perancangan pada bangunan yang berpengaruh terhadap perhitungan $\mathrm{ACH}$ adalah luas inlet/ bukaan tempat masuknya pergerakan udara ke dalam ruang yang dapat meningkatkan nilai $\mathrm{ACH}$ dan volume ruangan yang merupakan faktor pembagi dan dapat menurunkan nilai $\mathrm{ACH}$.

$$
N=60 \frac{0,5682 A v}{V}
$$

Keterangan:

- $\mathrm{N}=$ Jumlah air change per hour $(\mathrm{ACH})$

- $\mathrm{A}=$ Luas inlet $\left(\mathrm{m}^{2}\right)$

- $\mathrm{v}=\operatorname{Velocity}(\mathrm{m} / \mathrm{s})$

- $\mathrm{V}=$ volume ruangan $\left(\mathrm{m}^{3}\right)$

Kriteria minimum pertukaran udara per jam di Indonesia diatur dalam SNI 03-6572 2001 (Tabel 1).

Tabel 1. Standar pertukaran udara dalam ruang

\begin{tabular}{lccc}
\hline Fungsi ruang & \multicolumn{2}{c}{$\begin{array}{c}\text { Kebutuhan udara luar } \\
\left(\mathbf{m}^{\mathbf{3}} / \mathbf{m i n}\right) / \text { orang }\end{array}$} & \multirow{2}{*}{$\begin{array}{c}\text { Pertukaran udara } \\
\text { per jam }\end{array}$} \\
\cline { 2 - 3 } & Merokok & Tidak merokok & \\
\hline Ruang & - & 0,3 & 2 \\
keluarga & - & 3,0 & 20 \\
Dapur & 3,0 & 1,5 & 10 \\
Kamar mandi & 0,75 & 0,3 & 2 \\
Kamar tidur & \multicolumn{2}{c}{ Sumber: SNI 03-6752 2001 } \\
\hline
\end{tabular}

Berdasarkan rumusan perhitungan $\mathrm{ACH}$, nilai $\mathrm{ACH}$ dapat diperbesar dengan cara memperkecil volume ruang dan atau memperbesar luas inlet. Dikarenakan unit hunian merupakan bangunan yang memiliki modul struktur yang disebut RISHA maka diambil keputusan untuk hanya mengubah luasan inlet.

Besaran bukaan yang dapat diupayakan untuk memenuhi kriteria jumlah pertukaran udara minimum per jam adalah sebagai berikut. 
Untuk ruang keluarga

$$
\begin{aligned}
& 2=60 \frac{0,5682 \times A \times 0,5}{23,52} \\
& 2=\frac{17,046 \times A}{23,52} \\
& A=\frac{2 \times 23,52}{17,046}=2.76 \mathrm{~m}^{2}
\end{aligned}
$$

Untuk dapur

$$
\begin{aligned}
& 20=60 \frac{0,5682 \times A \times 0,5}{7.68} \\
& 20=\frac{17,046 \times A}{7.68} \\
& A=\frac{20 \times 7.68}{17,046}=9.01 \mathrm{~m}^{2}
\end{aligned}
$$

Untuk kamar mandi

$$
\begin{aligned}
& 10=60 \frac{0,5682 \times A \times 0,5}{4.92} \\
& 10=\frac{17,046 \times A}{4.92} \\
& A=\frac{10 \times 4,92}{17,046}=2.89 \mathrm{~m}^{2}
\end{aligned}
$$

Untuk kamar tidur

$$
\begin{aligned}
& 2=60 \frac{0,5682 \times A \times 0,5}{41.9} \\
& 2=\frac{17,046 \times A}{41.9} \\
& A=\frac{2 \times 41,9}{17,046}=4.92 \mathrm{~m}^{2}
\end{aligned}
$$

Besaran bukaan hasil perancangan ulang telah diupayakan untuk memperbesar hasil perhitungan nilai $\mathrm{ACH}$. Namun, keterbatasan unit hunian yang hanya memiliki satu bidang bukaan menjadikan luas bukaan yang dibutuhkan tidak dapat dipenuhi.

Hasil analisis dan perumusan solusi perancangan disimulasikan menggunakan software Autodesk Flow Design untuk mengetahui dampak dari solusi perancangan dalam mengalirkan pergerakan udara ke dalam ruang. (Gambar 15)
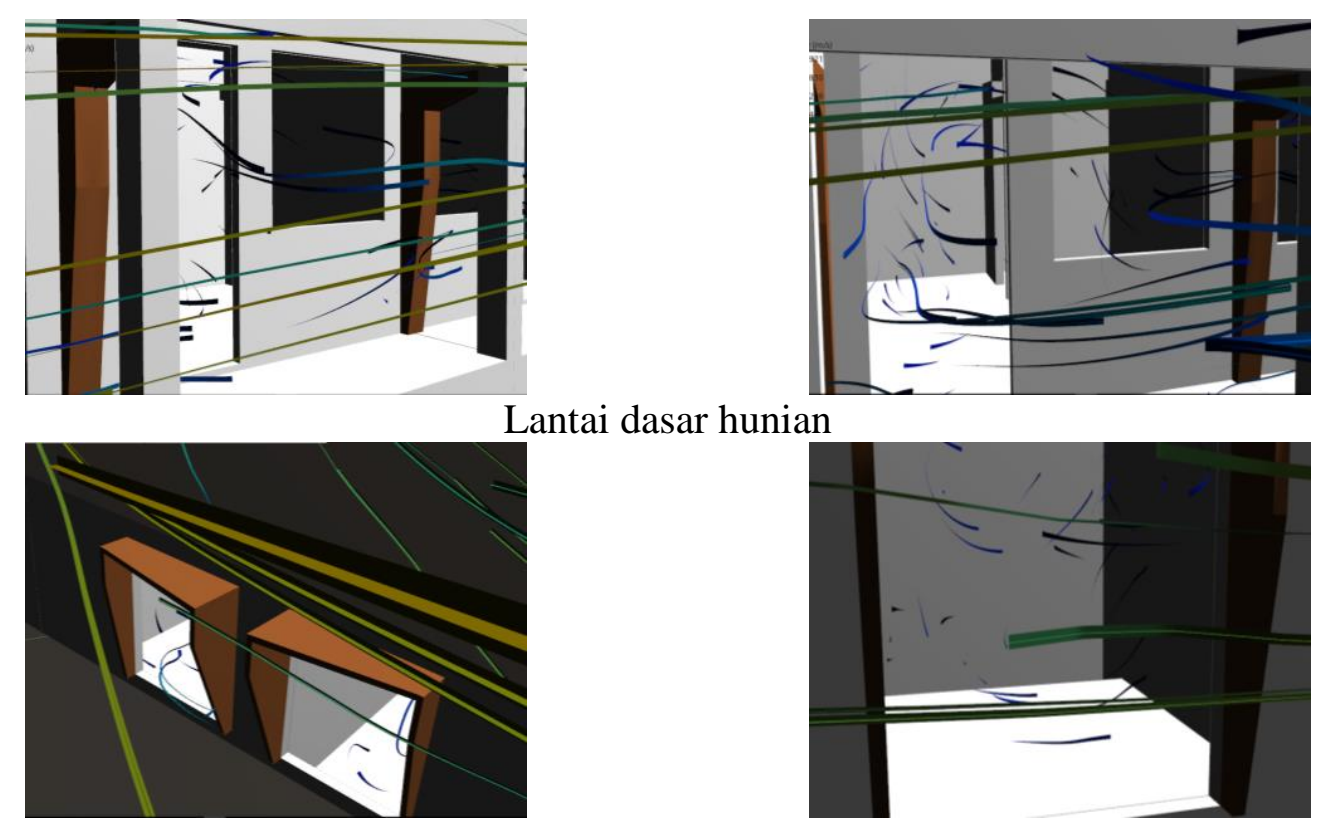

Lantai dasar hunian

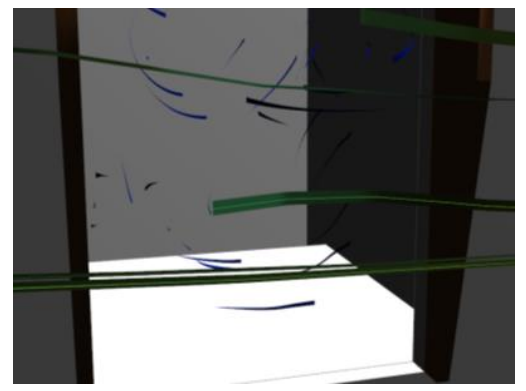

Lantai atas hunian

Gambar 15. Tipe jendela yang direkomendasikan 


\section{KESIMPULAN}

Hunian dengan konfigurasi deret memiliki karakteristik tersendiri yang kaitannya dengan pola pergerakan udara lingkungan dan bangunan yang membutuhkan optimasi tersendiri dalam perancangan tata massa dan bukaan bangunan.

Berdasarkan hasil penelitian, hal yang paling krusial untuk dipertimbangkan dalam perancangan rumah deret adalah:

- Mengatur panjang deretan bangunan untuk dapat memanfaatkan efek wind tunnel yang terdistribusi ke seluruh unit hunian.

- Memetakan pola aliran udara lingkungan untuk menjadi dasar perancangan dinding pengarah pergerakan udara sebagai teknologi yang membantu mengarahkan aliran udara masuk ke dalam bangunan

- Bukaan atap direkomendasikan untuk digunakan sebagai upaya untuk menurunkan suhu ruang atap melalui ventilasi silang

- Tipe bukaan yang direkomendasikan adalah tipe bukaan vertikal yang tidak mengubah arah pergerakan udara yang masuk ke dalam bangunan untuk menjauhi area living zone atau 0-2m dari permukaan lantai

- Dibutuhkannya simulasi perancangan menggunakan software sebagai acuan penerapan konsep desain pasif dalam mengalirkan pergerakan udara ke dalam ruang

\section{DAFTAR PUSTAKA}

Awbi, H. 2010, Basic concept for natural ventilation buildings, CIBSE BSG seminarnatural and mixed mode ventilation building, Reading, May 19

Baker, N. V. 1987, Passive and Low Energy Building Design: For Tropical Island Climates. The Commonwealth Secretariat, London.

Biro Analisa Anggaran dan Pelaksanaan APBN-SETJEN DPR-RI, 2015, Rencana Pembangunan Jangka Menengah 2015-2019 (http://www.dpr.go.id/doksetjen/dokumen/biro-apbn-apbn-Pembangunan-Perumahan1434526946.pdf, diakses 1 Juli 2017)

Boutet, Terry S. 1987, Controlling Air Movement, A Manual for Architects and Builders. McGraw-Hill, New York.

Brown, G. Z., Mark, D. K. 2001, Sun, Wind \& Light, Architectural Design Strategies Second Edition. John Willey \& Sons, New York.

Evans, M. 1980. Housing, Climate and Comfort. Architectural Press, New York.

Koenigsberger et. al. 1975, Manual of tropical housing and Building: part 1 Climate Design. Orient Longman Ltd, New Delhi.

Latifah, Nur Laela. 2012, Fisika Bangunan 1 modul 2 sistem pengahawaan alami dan Penerangan alami. Jurusan Teknik Arsitektur Institut Teknologi Nasional, Bandung.

Lechner, N. 2009, Heating, Cooling, Lightning Design Methods for Architects (third edition). John Willey \& Sons, New York.

Sabaruddin, A. 2017, Membangun RISHA: Rumah Instan Sederhana Sehat. Penebar Swadaya, Depok. 